\title{
Duminica oamenit n-AU porecle. SACRU Și PROFAN ÎN ANTROPONIMIA BULZEȘTIULUI
}

\author{
Elena-Camelia Zăbavă \\ Universitatea din Craiova, România
}

\begin{abstract}
On Sundays people do not have nicknames. Sacred and profane in the anthroponymy of Bulzești village (Dolj county)
\end{abstract}

\begin{abstract}
The purpose of this article is to illustrate the concepts sacred and profane according to Mircea Eliade's conception as they are reflected in the anthroponymy of Bulzesti, the home village of Marin Sorescu.

In our paper we analyze the two concepts, starting with a research about the anthroponyms in the volumes of poetry La Lilieci by Marin Sorescu. Then we present the current system of naming, and we emphasize that in the village described by the Romanian poet two such systems coexist. In the official one, people are named using their first and family names, especially on Sundays, when, according to the poet, "people do not have nicknames". The second system is the widespread, folk one, specific to Romanian rural society.
\end{abstract}

Keywords: sacred, profane, anthroponymy, system of naming, nicknames.

\section{Introducere}

În credințele populare românești zilele săptămânii sunt prezentate drept făpturi, care, în vremurile tare îndepărtate, umblau pe pământ, iar acest lucru ar explica de ce unele zile sunt bune și altele rele, de ce unele sunt îmbelșugate, iar altele nu. Se mai povestește, de asemenea, că există zile femeie și zile bărbat. Astfel, se spune că: Luni este bărbat și este bun pentru începutul tuturor lucrurilor. Tot el este acela care ține cheia de la cea dintâi poartă a cerului, iar atunci când se trece pragul spre lumea cealaltă, indică drumul pe care trebuie mers. Despre Marți se zice că este tot bărbat, dar e o zi rea, în care nu e recomandat să începi nimic și nici să pleci la drum. Miercuri e femeie, este o zi bună, solară, în care se postește pentru Maica Domnului. Urmează Joi, care e bărbat, și este o zi norocoasă. Se crede că este benefică dragostei și căsătoriei. Despre Vineri, de asemenea o zi femeie, se spune că este una dintre zilele cele mai încărcate de sacralitate. Vineri e sora Duminicii și stă sub semnul Crucii dătătoare de viață, pentru care se și postește. Sâmbătă e tot femeie, însă e zi nefastă, este ziua în care se aduc ofrande moșilor de neam. Se mai spune că nu este bine să se înceapă nimic, nici lucru, nici drum. Duminica, zi solemnă, festivă, luminoasă, este cea mai mare și mai frumoasă dintre toate, este ziua rugăciunii, a învierii, a bucuriei, a nunților și a jocurilor. Se povestește că Duminica e o sfântă înveșmântată în alb, care locuiește într-un palat de aur, dincolo de apa sâmbetei. 
Credința populară menționată mai sus o întâlnim consemnată și de Elena Niculiță-Voronca. Aceasta specifică următoarele:

Oamenii pe cari i-a făcut Dumnezeu au început a face la copii și tot făceau în toată ziua câte unul; aşa a vrut Dumnezeu ca să facă zilele. În ziua întâi a făcut pe Duminica, fată; apoi pe Luni, bărbat; pe Marți, bărbat; pe Miercurea, femeie; pe Joi, bărbat, apoi pe Vinerea, femeie, precum și pe Sâmbăta, ca să aibă oamenii sfinți zile (Niculiță-Voronca 1998: 38).

Denumită în lumea romană, înainte de creștinism, Ziua Soarelui (Dies Solis), apoi Ziua lui Dumnezeu (Dies Dominus), Duminica aparţine timpului sacru. În calendarul ortodox, duminica este prima zi a săptămânii, iar în tradiția creștină este ziua dedicată odihnei, familiei, este ziua în care oamenii participă la Sfânta Liturghie.

O figură binecunoscută și des întâlnită în basmele populare românești, dar și în cele culte, este Sfânta Duminică. Ea apare, de cele mai multe ori, în ipostaza unei femei bătrâne care ajută personajul principal să își îndeplinească misiunea, uneori oferindu-i în dar obiecte magice. De asemenea, sunt basme în care, alături de Sfânta Duminică, le întâlnim și pe Sfânta Miercuri și pe Sfânta Vineri. Întotdeauna cea mai puternică este Duminica. În articolul „Legenda Sfintei Vineri” - între sacru și diabolic, Raluca Levonian vede în motivul consultării sfintelor „un ecou al concepției religioase creștine: duminica este ziua cea mai importantă, care trebuie ținută cu orice preț, urmată în ordinea importanței de vineri și de miercuri. Creștinismul a consacrat ziua de duminică drept ziua de odihnă și cea în care a înviat Mântuitorul. Semnificația religioasă a secvențelor temporale este astfel antropomorfizată” (Levonian 2010: 84).

\section{Sacru şi profan în antroponimia satului sorescian}

Articolul de față urmărește modul de reflectare a sacrului și a profanului în antroponimia satului natal sorescian, Bulzești, județul Dolj, având ca punct de plecare o cercetare întreprinsă asupra antroponimelor din volumele La Lilieci.

În satul sorescian, ca de altfel în toate satele românești, viața se desfășoară în două dimensiuni temporale: una sacră, cealaltă profană, regăsind în felul acesta un timp sacru și un timp profan care vor influența și antroponimia satului.

„Ca și spațiul, Timpul nu este nici omogen și nici continuu pentru omul religios” - spunea Mircea Eliade, subliniind existența unor intervale de Timp sacru, cum ar fi timpul sărbătorilor (în cea mai mare parte periodice) pe de o parte, și a Timpului profan, pe de altă parte, reprezentat „de durata temporală obișnuită, în care se înscriu actele lipsite de semnificație religioasă” (Eliade 1995: 41).

Chiar dacă între cele două feluri de timp există o ruptură, „prin mijlocirea riturilor, omul religios poate „trece“ cu ușurință de la durata temporală obișnuită la Timpul sacru" (Ibidem).

Mircea Eliade observă o diferență esențială între cele două calități (de sacru și de profan) ale timpului: „prin natura sa, Timpul sacru este reversibil, în sensul că este de fapt un Timp mitic primordial readus în prezent. Orice sărbătoare religioasă, orice 
Timp liturgic înseamnă reactualizarea unui eveniment sacru care a avut loc într-un trecut mitic, „la începutul începuturilor“ (Ibidem).

„Omul religios trăiește astfel în două feluri de Timp, dintre care cel mai important, Timpul sacru, apare sub forma paradoxală a unui Timp circular, reversibil și recuperabil, un soi de prezent mitic regăsit periodic cu ajutorul riturilor” - arăta Mircea Eliade (Ibidem: 42).

\subsection{Antroponimia reflectată în dimensiunea Timpului sacru}

Pentru țăranii lui Marin Sorescu ziua de duminică este o zi sacră, un timp al sărbătorii; este ziua în care oamenii adoptă o conduită adecvată; merg la biserică, nu muncesc și... nu au porecle. Sunt numiți pur și simplu pe numele lor. În nicio duminică oamenii nu au porecle. Duminică de duminică, oamenii din Bulzești (și nu numai!) ies din durata temporală obișnuită, se leapădă de porecle, îmbracă haine de sărbătoare și revin la numele lor oficiale, se primenesc:

„Poate că lumea simte nevoia de primeneală după o / Săptămână pe câmp, / Ori în pleavă și praf la spatele mașinii de treierat...” (Sorescu 1986: 44).

În felul acesta, ei se reintegrează într-un timp sacru, actualizat de ziua de duminică. „Timpul sacru este deci mereu recuperabil și repetabil la nesfârșit” (Eliade 1995: 41). Prin urmare, fiecare duminică înseamnă regăsirea timpului sacru. Această teorie este susținută, în poezia lui Marin Sorescu, de folosirea adverbului de timp duminica, cu rolul de a imprima textului ideea de repetiție, de periodicitate, de reversibilitate.

„Duminica oamenii n-au porecle, / Li se spune curat pe numele cele bune / Care nu li se potrivesc deloc, ca hainele de moarte / Păstrate cu mare grijă în lacră” (Sorescu 1986: 44).

Numele, ca și hainele cele noi, de moarte, sunt neuzate, ele fiind folosite periodic, duminica.

Din dialogul purtat cu Nea Florea, poetul, în ipostază de copil, află cu nedumerire că Nea Dumitru Seder este de fapt cel pe care îl recunoștea cu porecla Bag-Seamă:

„-De ce-i zici Nea Dumitre? Ăsta nu e Bag-Seamă? / Întreb eu, nedumerit. / - Ei, râde Nea Florea, asta e porecla, dar pe el îl cheamă / Dumitru Seder, de ispravă om!" (Ibidem).

Așa sunt aflate „...o mulțime de nume noi, șterse, care nu spun nimic, / Nume de pomelnic, n-au nici o legătură cu frumusețea / Poreclelor” (Ibidem: 45).

Astfel, Primăvara este Ioniță Cucu. „Pe Șoalda lui Cazacu o cheamă Țața Floarea, / Pe Spânzu - Ion / Pe Focu- tot Ion / Pe Dârmon - Fane Dragu / Pe Boc - Titu Seder / Pe Ciușe... - îl cheamă Popescu / ...Pe Civică - Amărăzeanu / Pe Guiț - Gogu” (Ibidem: 46).

Obișnuiți să se recunoască între ei după poreclă (unii au câte două, trei: lui Popescu i se spune Ciușe sau Nete), numele oficiale li se par străine, pocite, după cum zicea Nea Florea. Ele sunt comparate cu apa sălcie: „Apa aia de nu spală și nu fierbe fasolea. / Dar duminica este păcat să poreclești lumea” (Ibidem). 
Prin urmare, ceea ce este folosit în mod obișnuit în cursul săptămânii, utilizarea frecventă a poreclelor, în proiecția Timpului sacru, duminica, devine păcat. Mutu:

O singură excepție se face de la această regulă în satul lui Sorescu. Este vorba de

„Și pe Mutu ei, cum îl mai cheamă? întrebam eu, / să aflu totul până la capăt. / -Păi, ...tot Mutu. Ăstuia n-ai ce-i mai face, / Așa l-a lăsat Dumnezeu. / E mut și-n ziua de paști, săracul” (Ibidem). În acest caz, porecla este admisă și duminica pentru că geneza ei pleacă de la o infirmitate acceptată, față de care oamenii arată compasiune și nu are conotații peiorative.

De asemenea, duminica este ziua în care are loc ieșirea în lume: „Ieșirea în lume este la poartă, duminica” (Sorescu 1986: 27), când oamenii, îmbrăcaţi de sărbătoare „Dau bună ziua de departe și au timp să schimbe / Și două, trei vorbe”, când totul pare proiectat într-un timp mitic: „Li se descoperă numai părțile bune / Și îmi apar într-o lumină nemaipomenită, lăptoasă, / Parcă toți ar fi ctitori de fântâni cu cumpănă” (p. 27). Acum toți oamenii sunt mai buni, mai permisivi, mai înțelegători cu cei din jurul lor. În finalul poemului Lumea albă, o bătrână bolnavă vrea să privească, din pat, pe fereastră, lumea albă. Când cineva spune: „-Asta ce-o mai fi vrând să vadă, săraca? / I-o fi moartea sub pat, odată îi face „bau”... urmează replica plină de compasiune: „- Ei, mă, vrea să se mai uite și ea la lume, că e / Duminică / Și să mai vadă și ea lumea” (Ibidem).

\subsection{Antroponimia reflectată în dimensiunea Timpului profan}

În satul lui Marin Sorescu, Timpul profan are ca limită de desfășurare zilele lucrătoare ale săptămânii. Este cunoscut faptul că, în mod obișnuit, într-o comunitate rurală restrânsă oamenii se recunosc între ei cu ajutorul poreclelor sau cu ajutorul formulelor populare de denominație, în special cele obținute prin construcții genitivale de tipul: Sandu lui Ciurel, Floarea lui Ghiță, Mița lui Vasile, Ioana lui Prăzaru. Acestea sunt întâlnite în număr foarte mare în La lilieci: Floarea Păunii, Sandu lui Chioveanu, Veta lui Iedu, Mutu Ioncicăi, Gogu lui Duluman, Dumitru lui Chirimențu, Lache al lui Pătru, Dorel al lui Bălteanu, Ionete al lui Făsui, Coadă al lui Ceapă, Costică al lui Coadă al lui Ceapă, Petrică lui Cășenete, Frusina lui Coadă, Ion al lui Ion ăl Mic, Mitru lui Ciugulea, Sandu lui Cină, Fănică al lui Ciucă, Ioniță al lui Cucu, Sandu lui Moisă, Vîrlan al lui Ioane, Gică al lui Rinu, Mitru lui Viță, Pătru lui Gogu, Fănică al Banții, Ilie al lui Mandă, Dumitru lui Nistor, Nicolae al lui Codin, Nae al lui Urezeanu, Sandu lui Moisă, Mitrică al lui Nete, Dinu lui Foloiu, Ioniță al lu’ Burghiu, Vitilina lui Petrică, Măria Bălii, Marin al lui Pătru, Rine al Cazacăi, Grigore al lui Tăgărâlă, Lina lui Victor, Dumitru lui Enache, Ștefan al lui Mandă, Dinu lui Voicu, Măria lui Rinu, Ion al Floarii, Marin al Maricăi, Nițu al Cincăi, Manda lui Chiligean, Constanța lui Cotoarbă, Anica lu'Mitu, Tilina lui Surdu, Nițu al Nițăi, al lui Bâtu etc.

În volumul Expresie populară în ciclul La Lilieci de Marin Sorescu, acad. Grigore Brâncuş precizează că la numele de persoană formate cu genitivul „nu apare niciodată substituția printr-o construcție prepozițională ca în cazul numelor comune: acoperișul (de) la casă = acoperișul casei” (Brâncuș 2014: 43). 
De asemenea, lingvistul face observația că termenul în genitiv poate fi un nume masculin (Vasile, Pătru, Nistor, Petrică, Victor etc.) sau feminin (Ioncica, Floarea, Marica, Păuna etc.), un nume de familie (Banța, Bălteanu, Manda, Urezeanu etc.), un hipocoristic (Rinu, Gogu, Ghiță), un supranume sau o poreclă (Duluman, Cucu, Făsui, Ceapă, Burghiu, Foloiu etc.).

Ceea ce îi atrage în mod deosebit atenția academicianului Grigore Brâncuș este faptul că:

Dintre cele două componente, important este cel în genitiv, a cărui alegere are determinări variate, exterioare limbii. Acesta poate fi numele unuia dintre părinți, bunici, străbunici sau soți, numele de familie, un supranume, o poreclă, construcția, în întregul ei, exprimând un raport de filiație, de alianță, de apartenență, în general, un raport de rudenie (Brâncuş 2014: 44).

Acest tip de formule denominative este deosebit de des întâlnit în spațiul rural, el fiind cu adevărat util comunităților sociale restrânse în care oamenii se cunosc foarte bine între ei deoarece sunt fie neamuri, fie vecini, realizându-se astfel interdependențe sociale sau economice. Printr-o asemenea formulă se raportează individul la un membru al familiei a cărui importanță este recunoscută din punct de vedere economicosocial. Există în La Lilieci un episod care, pe lângă nota ironică înmagazinată, subliniază încă o dată importanța formulei genitivale în viața satului: „- Și cine spune prostia asta? / - Marx, nu-ți spusei! / - Și Marx ăsta al cui e?/ Tăcere. / George știa că aici trebuia să-i / răspundă: 'al lui Cutare, al lui Cutare', / cum erau ei: Marin al Nicoliței a lui Fănică / al lui Ion Bălan - Sorescu- / toți de-aci, într-un nume, așa se țineau oamenii, / uniți, la noi - / și se deosebeau unii de alții. / -Ei! Zice el ...n-are importanță / al cui e...și-a negat părinții / că erau 'burghezi'. / -Păi vezi!... / -Păi ce să văd? / -Că se lepăda și de tac'su / şi de mă-sa!" (Sorescu 2010: 389-390). Dincolo de faptul că susținea o idee absurdă cu care Nicolița nu putea fi de acord, Marx nu avea nici măcar o minimă credibilitate în ochii femeii, deoarece nu prezenta nicio afiliere.

În analiza lingvistică aplicată textului sorescian din La Lilieci, Grigore Brâncuș a remarcat că, în formulele de acest gen, elementul stabil este numele de botez, termenul în genitiv putându-se schimba în funcție de diferitele împrejurări din viața individului.

De multe ori, cu scopul de a evita unele confuzii sau pentru o mai bună individualizare, se folosește raportarea unei persoane la mai mulți membri ai familiei sale: Țața Nicolița a lui Fănică al lui Ion Bălan, Ionică al Nicoliței lui Fănică al lui Ion Bălan, Marin al Nicoliței a lui Fănică / al lui Ion Bălan, Constandin al Dinei a lui Dineață, Gogu lu' Mitru Măriei lu' Niță, Trică al lui Trașcă al Linei a lui Stanciu, Dumitru lu'Dumitru al lu' Dumitru, Marin al lui Mitru lu' Graure; alteori este suficient numai determinantul în genitiv: al lui Flețu, ai lui Fleașcă, al lui Tălmaciu, al lui Deșca, ai lui Mitrofan, ai lui Modârlan, ai lui Corniță, ai lui Ghirea, ai lui Birău, ai lui Zgoidea, ai lui Zăbic, ai lui Roșca, al lui Geică, ai lui Capete etc.

Poreclele reprezintă o altă modalitate de manifestare antroponomastică proiectată 
în Timpul profan. Ioan Aurel Candrea considera că ele sunt „cuvinte prin care poporul lovește în năravul sau defectul cuiva". (Candrea 1895: 8). Acestea se bucură de o largă răspândire în antroponimia rurală și au, în primul rând, rol de satirizare, iar în al doilea rând, individualizează sau îndepărtează omonimia din onomastica oficială.

Foarte pitorești, poreclele din La Lilieci trimit cu ușurință la spațiul geografic localizat, satul Bulzești, din „inima Olteniei”: Bălan, Bâț̦u, Graure, Gâtlan, Pupuță, Cheie, Scorbelici, Spânu, Bag-Samă, Păsărică, Mutu, Târziu, ăl Moale, Pămală, Purcea, Șoalda, Țiganu, Duduianu, Băzgărău, Ciușe, Nete, Zgoidea, Ceapă, Ciurel, Bășină, Făsui, Iedu, Focu, Fleașcă, Flețu, Balamuc, Cucu, Spânzu, Dârmon, Boc, Civică, Guiț, Șubăscurtă, Gârlă, Gâscă, Tiugă, Ciuciu, Golumbeanu, Mițăle, Corniță, Noatinul, Prăzaru, Roască, Spânu, Sfoiag, Vulpe etc., astfel încât „cuvintele regionale alunecă parcă firesc spre numele proprii (Făsui, Golumbeanu, Ciuciu, Prăzaru)” (Zăbavă 2007: 82).

Referitor la modul de formare a poreclelor, se poate afirma că acestea au luat naştere prin conversiune antroponimică, derivarea sau compunerea având loc la nivelul limbii comune.

De multe ori, în textul Liliecilor regăsim geneza acestor porecle: lui Gheorghe Ionescu, logofătul de la Velești, adică notarul, lumea îi zicea și Prăzaru, fiindcă tatăl său „venise în Bulzești de la Amăradia, unde se cultivă mult praz. Grigore al lui Tăgârlă a primit porecla ăl Moale în urma întâlnirii de „la Cișmele” „cu unul care cam sclipea de departe. / Așa ca putregaiul” (Sorescu 1986: 92), Marin al lui Moșu Pătru era poreclit Târziu pentru că se apropia de 50 de ani și nu se hotăra să se însoare (Ibidem: 77); Mitru al lui Viță este poreclit Pămală fiindcă era „mare, bloncos, purta căciula pe-o parte” (Ibidem: 201), lui Gogul lu' Mitru Măriei lu’Niță îi ziceau Gâtlan pentru că avea gâtul lung (Sorescu 2010: 10), bunicul poetului, Ion Bălan Sorescu avea porecla Bălan pentru că avea „părul alb, alb” (Sorescu 2010: 26).

De asemenea, se întâlnesc situații în care aceeași persoană are două porecle, ambele fiind folosite pentru identificarea purtătorului lor: este cazul lui Radu Țiganu „Că peste Radu Țiganu mai avea o altă poreclă: Duduianu” (Sorescu 1986: 231), iar lui Popescu i se spune Ciușe sau Nete (Ibidem: 46).

$\mathrm{O}$ caracteristică a mediului rural este aceea că aproape toți oamenii au porecle. $\mathrm{O}$ particularitate fizică sau psihică, o întâmplare, o deprindere, un cuvânt sau o expresie des folosite, o anumită preferință devine, fără prea mare greutate, o poreclă (PopescuSireteanu 1999: 238).

Trebuie remarcat numărul mai mic al poreclelor atribuite femeilor: Auricăi din Neică, neică (Sorescu 1986: 175) i se zicea Pucioasa, iar țaţa Floarea din Duminica oamenii n-au porecle (Ibidem: 44) este Șoalda lui Cazacu. De cele mai multe ori, femeia este cunoscută printr-un derivat de la porecla soțului: Golumbeanca - Golumbeanu, Popoveanca - Popoveanu, Cheaga - Cheagu, Chirimeanța - Chirimențu, Ciudinca Ciudin, Grăuroaica - Graure, Foaca - Focu, Cepoaia - Ceapă, Cuca - Cucu, Țoțuleasa - Țoțu (Zăbavă 2007: 83).

Tot în Timpul profan se mai poate întâlni un alt tip de denominație neoficială: supranumele. Printre primii cercetători care s-au ocupat de studiul poreclelor și al 
supranumelor este Ștefan Pașca. Acesta, în cunoscuta lucrare Nume de persoane și nume de animale din Țara Oltului, face disticție între funcția poreclei și cea a supranumelui (deși cele două categorii antroponimice sunt asemănătoare, deseori facându-se confuzie între ele): supranumele „are o funcțiune exclusiv antroponomastică, pe când porecla indică o funcțiune semantică. Porecla se dă ca o batjocură unui individ, incidental, supranumele, născut din porecle și calificative sunt legate indisolubil de numele indivizilor, devenind chiar ereditare” (Pașca 1936: 44).

Fără să ne propunem realizarea unei analize teoretice a celor două noțiuni: poreclă și suprapune, dorim să subliniem două lucruri pe care le considerăm importante: a) faptul că amândouă aparțin sistemului popular de denominație, care este mai flexibil decât cel oficial și care permite utilizarea acestor două substitute ale numelui (fie ale prenumelui, fie ale numelui de familie) și b) porecla și supranumele apar în împrejurări nonconvenționale, fapt ce duce la acceptarea cu ușurință a unor schimbări în cadrul sistemului neoficial de denominație, în vreme ce sistemul oficial nu acceptă asemenea schimbări decât rar, în consens cu legislația în vigoare.

Redăm în continuare câteva exemple de supranume individuale sau de grup extrase din ciclul La Lilieci: Mitru Tălmaciu, Marin Clanaristul, Păun Murgășanu, Ion Poștaru, Mitică Tâmplaru, Ghiță Lăutaru sau Brânzanii, Bănțeștii, Căpeții, Caloteștii, Ciuculeștii, Ninoii, Ștefăneștii etc.

O altă reprezentare a profanului în antroponimia Liliecilor este credința panbalcanică potrivit căreia, în cazul unei boli foarte grave, în multe cazuri epilepsia, trebuia schimbat numele de botez pentru a înșela boala. Utilizarea unui nou nume, a unui nume-mască, avea menirea să îl ferească de boli și de duhuri rele pe purtătorul lui. Un asemenea episod este surprins de Marin Sorescu și redat cu lux de amănunte, dar și cu binecunoscuta-i ironie: „N-a scăpat de râie neam, / Până nu și-a schimbat numele, / Îl chema Vasile. / Și numele ăsta se învățase cu râia / ...Și l-a schimbat din Belitu Vasile / În Belitu Gheorghe” (Sorescu 2010: 328). În continuare, poetul descrie întreg ritualul de schimbare a numelui: mersul în cimitir împreună cu nașul și încă un vecin, interdicția de a vorbi, îngroparea hainelor la piciorul crucii, strigarea de trei ori a numelui vechi cu fața către cimitir și de trei ori a numelui nou cu fața către sat.

Se pare că acest obicei nu este deloc necunoscut mediului rural din spațiul oltenesc. Despre el vorbește și medicul Ch. Laugier în studiul Sănătatea în Dolj. Monografie sanitară, apărut la Craiova 1910 și reeditat în 2010:

Se schimbă numele când copiii mici se îmbolnăvesc fie dupe 'pierit' fie de epilepsie. Primul copil născut viu - dupe unul sau mai mulți născuți morți dar la termen - se numeşte dupe 'pierit'. Acestui prim copil viu îi să schimbă numele adesea, îi să îngăure urechia şi îi se pune un cercel pe care stă scris al doilea nume. Cel dintâi nume să scrie pe o cărămidă care s’aruncă într'un râu. [...] Altădată când copilul n'a fost tămăduit dupe încercările de mai sus să dă de 'Bogdea-proste' adică copilul bolnav să grijeşte de preot, printre foarfeci deschişi şi peste mormântul unui necunoscut, şi o altă persoană primeşte copilul peste mormânt zicând 'Bogdea-proste' (Laugier 2010: 45). 
Doctorul Laugier, la obiceiul schimbatului numelui, mai aduce unele precizări: faptul că se găurește urechia copilului, chiar dacă este băiat, și i se pune un cercel pe care este inscripționat al doilea nume care trebuie să îl scape și să-l ferească de boală. Și în satul sorescian se mai crede acest lucru. Este vorba despre Ioniță Cucu, pe care Marin Sorescu îl descrie astfel: „Dar bănuțul tot strălucitor la ureche. / -I-a murit un frate și ca să nu ajungă moartea / Și la el, că e singurul moștenitor, i s-ar stinge neamul, / Și-a pus banul ăla gălbui la urechea stângă" (Sorescu 1986: 44).

De altfel, nu este pentru prima dată când se semnalează în literatura română această credință a poporului nostru că, în anumite cazuri, numele este vinovat pentru problemele de sănătate ale oamenilor și soluția imediată este schimbarea acestuia cu un altul care să le ofere protecție. Deși în altă arie geografică, despre acest obicei al schimbării numelui vorbește și Mihail Sadoveanu în cunoscutul său roman Baltagul:

Gheorghiță era numele care plăcuse Vitoriei, căci era numele cel adevărat şi tainic al lui Nechifor Lipan. Acest nume i-l rostiseră preotul şi nânaşii la sfântul botez, când îl luminaseră cu aghiazmă şi cu mir întru credința cea adevărată. Însă într-al patrulea an al vieții se bolnăvise de hidropică şi atâta slăbise încât au fost poftiți preoți de i-au făcut sfintele masle. Atuncea, după masle, a venit şi țiganca cea bătrână a lui Lazăr Cobzarul, şi maică-sa i l-a vândut pe fereastră luând preț pentru el un bănuț de aramă. Primindu-l de la mama lui, Cobzărița i-a suflat pe frunte descântând, şi i-a schimbat numele, ca să nu-l mai cunoască bolile şi moartea. De-atunci i-a rămas numele Nechifor (Sadoveanu 1987: 25).

\section{Concluzii}

În concluzie, putem afirma, așa cum arăta și academicianul Grigore Brâncuș în studiul său dedicat expresiei populare din poezia Liliecilor, că numele de persoană întâlnite aici „au un caracter vechi și popular, sunt cunoscute mai ales în partea de sud a țării” (2014: 34). Ele fac trimitere la credințe străvechi, conform cărora numele are rol protector sau surprind modul în care oamenii se numesc și se recunosc între ei atât duminica, în Timpul sacru, cât și în restul săptămânii, în Timpul profan.

Bulzeștiul este un sat tradițional de câmpie, în care obiceiurile și credințele străvechi sunt respectate, iar cele care fac trimitere la nume nu fac excepție.

\section{Bibliografie}

Brâncuş, G. 2014. Expresie populară în ciclul La Lilieci de Marin Sorescu. Bucureşti: Editura Academiei Române.

Candrea, I. A. 1896. Poreclele la români. Bucureşti

Eliade, M. 1995. Sacrul şi profanul. Brânduşa Prelipceanu (trad.). Bucureşti: Editura Humanitas. Laugier, Ch. 2010. Sănătatea în Dolj. Monografie sanitară. Craiova: Editura INFO.

Levonian, R. 2010. Legenda Sfintei Vineri - între sacru şi diabolic. Philologica Jassyensia 1 (11): 84.

Niculiță-Voronca, E. 1998. Datinile şi credințele poporului român adunate ş̧i aşezate în ordine mitologică, vol. I, Ediție îngrijită de V. Durnea. Iaşi: Editura Polirom. 
Popescu-Sireteanu, I. 1999. Porecle şi supranume din satul Drăguşeni, com. Şcheia, județul Iaşi. Studii şi Cercetări de Onomastică 4 (2): 242.

Sadoveanu, M. 1987. Baltagul. Bucureşti: Editura Ion Creangă.

Sorescu, M. 1986. La Lilieci (I-III). Bucureşti: Editura Cartea Românească.

Sorescu, M. 2010. La Lilieci (IV-VI). Bucureşti: Editura ART.

Zăbavă, C. 2007. Marin Sorescu - La Lilieci: nume şi poreclă: Philologica Jassyensia 3 (1): 82. 